\title{
THE CONTRIBUTIONS OF THE COUNCIL OF TRENT TO THE CATHOLIC REFORMATION
}

\author{
ROBERT FASTIGGI*
}

Sacred Heart Major Seminary

\begin{abstract}
This article begins by examining what is meant by the Catholic Reformation and how it relates to the other frequently used term, Counter-Reformation. It then discusses the different ways Catholics and Protestants in the early 16th century understood ecclesial reform. Next there is a consideration of the call for a general or ecumenical council to resolve the differences between the Catholics and Protestant reformers; the reasons for the delay of the council; and the reasons why the Protestants did not participate. The article then provides a summary of the three main periods of the Council of Trent: 1545-1547; 1551-1552; and 1562-1563 along with the 1547-1549 Bologna period. This is followed by a detailed overview of the reforms of the council, which were both doctrinal and disciplinary. The article shows that, while abuses related to various Catholic practices and the sacraments were addressed, the main concerns in the various disciplinary decrees related to clerical corruption and immorality. The article addresses the need for bishops to reside in their dioceses; stop clerical corruption, greed, and nepotism; and establish seminaries for the proper formation of priests. After the review of the disciplinary reform decrees, attention is given to the Catechism of the Council of Trent that served as a resource for parish priests in their instruction of the faithful. The final section considers viewpoints of different historians regarding the effect of the Council of Trent on reform within the Catholic Church.
\end{abstract}

KEY WORDS: Council of Trent, Catholic Reformation, Counter Reformation, clerical corruption, Catechism of the Council of Trent.

\section{Introduction: The Catholic Reformation and the Counter-Reformation}

Historians sometimes make a distinction between the Catholic Reformation and the Counter-Reformation. Hubert Jedin (1900-1980), the great historian of the Council of Trent, described the Catholic Reformation as 'the church's remembrance of the Catholic ideal of life through inner renewal', and he described the Counter-Reformation as 'the self-assertion of the Church in the struggle against Protestantism' (O’Malley 2000: 55). The Catholic Reformation sometimes is also distinguished from the Counter-Reformation because there were movements of reform within western Catholicism prior to the Protestant Reformation (Hildebrand 1996: 287). In the Middle

* $\quad$ ROBERT FASTIGGI (PhD Fordham University, 1987) is Professor of Systematic Theology at Sacred Heart Major Seminary, Detroit. Email: fastiggi.robert@shms.edu 
Ages, there was the Gregorian reform under Pope Gregory VII (1073-1085) and the reform movements of the Dominicans and the Franciscans during the thirteenth century (Olin 1969: xviii-xix). The Catholic Reformation, however, is usually identified with the reform movements within the Catholic Church of the 16th and 17 th centuries. In this respect, the Counter-Reformation, I believe, should be understood as one phase within the broader Catholic Reformation of this period.

Understood in this broader sense, the Catholic Reformation prior to the Counter Reformation would include the Florentine Dominican preacher, Girolamo Savonarola (1452-1498) whose 1495 sermon 'On the Renovation of the Church' warned of ensuing punishments because of corruption and 'the pollution of the prelates' (Olin 1969: 5). Because of his conflicts with Pope Alexander VI (r. 1492-1503), Savonarola was accused of heresy and executed on May 23, 1498 (Gregory 2012: 261). Another Catholic reformer was the Italian mystic, St. Catherine of Genoa (1447-1510), who helped to establish the 'Oratory of Divine Love'. There was also the Spanish humanist, Cardinal Francisco Ximénez de Cisneros (1536-1517), who promoted biblical studies. Other humanists such as John Colet (c. 1466-1519) and Desiderius Erasmus (c. 1469-1536) were likewise part of the Catholic Reformation as was Egido da Viterbo (1469-1532), whose address at the Fifth Lateran Council in 1512 called upon the Holy Spirit to cleanse the Church 'from every stain' and restore it 'to its ancient splendor and glory' (Olin 1969: 53).

During the time of the various Protestant reform movements, the Catholic Reformation saw the rise of new religious communities such as the Capuchins (1528), the Ursulines (1535), and the Jesuits (1540). This was also vigorous Catholic missionary activity in the Americas and the Far East. This era produced outstanding achievements in religious art, architecture, and music as well as mystical writers such as St. Philip Neri (1515-1591), St. Teresa of Ávila (1515-1582), and St. John of the Cross (1542-1591). These movements of reform with the Catholic Church were not simply reactions to the Protestant reform movements. They instead were part of a more extensive impulse of reform that had been stirring in the Catholic Church since the late $15^{\text {th }}$ century and early 16 th century.

The Catholic Reformation was primarily concerned with moral and spiritual reformation in light of clerical worldliness and immorality. Many priests were not well educated, and many of the faithful were poorly catechized. The impulse of the Catholic Reformation was reformatio in capite et in membrisreformation in the head and in the members-which was a motto attributed to William Durandus at the time of the 1311-1312 Council of Vienne (Olin 1969: xix). The Protestant Reformation, however, was concerned with doctrinal and structural reforms. The Protestant reformers believed the problems in the Church were not merely due to moral laxity. 
They instead were due to doctrinal and structural errors that had entered into the Church since the time of Christ and the Apostles.

The beginning of the Protestant Reformation is usually linked to the 95 theses of Martin Luther (1483-1546) of October 31, 1517. There were, of course, other Protestant reformers such as Ulrich Zwingli (1484-1531), John Calvin (1509-1564), and the Anabaptist, Meno Simons (1496-1561). The actual term, Protestant, derives from the protestatio issued by six princes and fourteen imperial cities of southern Germany protesting the decision of the 1529 Diet of Speyer that forbad any more innovations in religion until there was a general council (Bihlmeyer-Tüchle 1966: 37-38).

\section{The Call for a General Council}

The call for a general council had actually been made by Luther himself in 1519 (Bettenson and Maunder 2011: 203). At the Diet of Worms in 1521, however, Luther revealed that he put no trust in the unsupported authority of Pope or of councils (Bettenson and Maunder 2011: 214). The Holy Roman Emperor, Charles V (1500-1558), favored holding a general council, and the Diet of Nuremberg of 1523 called for 'a free, Christian Council on German soil' (Jedin 2003: 168). Pope Clement VII (r. 1523-1534), however, feared that such a council would fall prey to a conciliarism that devalued papal authority. He likewise feared that laymen as well as bishops would be allowed to vote and there would be a demand for all judgments to be 'exclusively based on the Scriptures' (Jedin 1960: 146). Moreover, the Fifth Lateran Council (1512-1517) had concluded only a few years earlier, and Clement VII knew that the King of France, Francis I, would not support a general council held on German soil because it might increase the power of his political opponent, Charles V (Jedin 1960: 148). After Charles V failed to reach an agreement with the Lutherans at the Diet of Augsburg in 1530, he again appealed to Pope Clement VII to summon a general council. Clement VII finally agreed, but he placed so many conditions on the holding of the council that it never materialized (Jedin 2003: 168).

Charles V had more success with Clement VII's successor, Paul III (r. 1534-1549) in opening a general council. The first agreement was for the council to begin on May 23, 1537 at Mantua, which at that time was a fief of the Empire. This effort, though, failed because of the outbreak of a new war between Charles V and Francis I of France and also because of the Duke of Mantua's demand for a guard of some five to six thousand men with their pay guaranteed (Jedin 1960: 149). Paul III then transferred the council to Vicenza, but very few bishops showed up, and the council was cancelled.

These failed attempts to open the council, however, were not completely in vain. In November 1536 a commission of nine reform-minded bishops and religious superiors met in Rome under the leadership of Cardinal 
Gasparo Contarini. Over the course of three months, they drew up a plan for Church reform entitled the Consilium de emendanda ecclesia. This plan was presented to Paul III in early March of 1537 (Olin 1969: 183). This Consilium exposed a number of abuses that needed to be addressed. One of these was the indiscriminate ordination of 'the most unskilled, men of the vilest stock and of evil morals' as well as 'adolescents' (Olin 1969: 188). Other abuses mentioned were the granting of ecclesiastical benefices with income without any expectation of pastoral service; absentee priests and bishops; and 'the absolution of those guilty of simony' (Olin 1969: 195). These abuses would be addressed later at the Council of Trent.

After the futile attempts to hold a general council in Mantua and Vicenza, Charles V once again tried to heal the divisions with the Protestant reformers. Paul III sent Cardinal Contarini as his delegate to the Diet of Regensburg of 1541. Agreements, however, could not be reached on matters such as justification, the nature of the Church, and transubstantiation of the Eucharist.

Cardinal Contarini 'declared that any further concession would only lead to a sham accord (concordia palliata)' with the Protestant reformers (Jedin 1960: 152).

Paul III now saw the need for a general (i.e. ecumenical) council to respond to the challenges of the Protestant reformers and to seek Church reform. The location of Trent was agreed upon because it 'belonged to the Empire but was of easy access from Italy and a predominantly Italian city' (Jedin 1960: 152). The council was set to begin in May of 1542, but a new war between France and the Empire forced another delay. The Peace of Crépy in September 1544 finally opened the way for the convocation of the council by means of the bull Laetare Jerusalem of November 19, 1544. This bull established three main aims for the council: 'healing of the confessional split, reform of the Church, and establishment of peace so that a defense against the Ottomans could be elaborated' (Jedin 2003: 168).

\section{The Council of Trent and its Three Periods}

The Council formally began on December 13, 1545 with 'no more than thirtyone bishops, most of them Italians' (Jedin 1960: 155). Because of the failed attempt at reconciliation with the Protestants at the 1541 Diet of Regensburg and the refusal of the Protestants to participate in a council under papal authority, 'arrangements were made for a strictly Catholic ecclesiastical assembly' (Bihlmeyer-Tüchle 1966: 103). In the Decree on the Profession of Faith of February 4, 1546, the Council noted its two principal objectives: 'the eradication of heresies and the reform of morals' (Denzinger-Hünermann 2012: n. 1500 , p. 369).

The Council of Trent lasted from December 13, 1545 to December 4, 1563 with three Tridentine periods and a two-year period in Bologna (Denzinger- 
Hünermann 2012: pp. 368-369). The first Tridentine period lasted from December 1545 to March 1547, and it included sessions 1-8. During these sessions, doctrinal decrees were issued on the reception of the Sacred Books and Tradition (April 8, 1546); original sin (June 17, 1546); justification (January 13, 1547); the sacraments in general (March 3, 1547); and baptism and confirmation (March 11, 1547).

Because of an epidemic of typhus, the council was transferred from Trent to Bologna (Jedin 1960: 164) where sessions 9-10 of the council were held. A minority of 14 bishops-mostly subjects of Charles V-protested the transfer and remained in Trent. The bishops, religious superiors, and theologians who assembled in Bologna engaged in important discussions on the sacraments of penance, extreme unction, orders, and the Eucharist as well as the Mass as sacrifice, purgatory, the veneration of the saints, and monastic vows (Jedin 2003: 170). The Bologna period lasted from March 1547 until September 1549 with a period of suspension in 1548 due to protests of the emperor.

During the time of suspension, Charles V tried to work out an agreement with the Protestants at what is called the Interim of Augsburg. He and his Catholic representatives were willing to make certain concessions such as communion under both species and married priests, but agreement was not achieved on other matters. The Protestants at the Interim of Augsburg agreed to send representatives to the council if it returned to Trent and certain conditions were made. These conditions, however, included the provision that the council 'must not be subject to the guidance of the Pope, and that the decrees already approved by Trent must be replaced by new ones' (Jedin 1960: 167). Such conditions, of course, were not acceptable to the pope.

Paul III died on November 10, 1549, and his successor, Julius III (r. 15501555), yielded to the pressure of Charles $\mathrm{V}$ and agreed to return the council to Trent. The council resumed at Trent on May 1, 1551 and continued until April 28, 1552 when it was suspended because of the revolt against Charles V 'by the German princes allied with France' (Jedin 2003: 171). Sessions 1116 of the council took place during this second Tridentine period, and some significant doctrinal decrees were issued. On October 11, 1551, the decree on the Eucharist was promulgated, and on November 25, 1551, the decrees on the sacraments of penance and extreme unction were approved.

In January of 1552 some Protestant delegates arrived at the council after being given assurance of safe-conduct. These delegates, however, insisted that any decrees of the council already approved would need to be revised and based solely on Scripture. They also wanted to subordinate the authority of the pope to the authority of the council, which was a policy explicitly rejected by Council of Florence in 1439 (Denzinger-Hünermann 2012: n. 
1309 , p. 337). Because such demands were impossible for the pope and the bishops to accept, this would be the first and only time that Protestant theologians appeared at Trent (Jedin 2003: 171).

After the suspension of the council on April 28, 1552, there was a ten-year interlude before the council once again resumed. During this interlude, Julius III in 1553 prepared an extensive bull for the reform of the Church, but he died before its publication (Jedin 2003: 171). Pope Paul IV (r. 1555-1559) thought it would be more efficient to undertake needed reforms by a papal assembly rather than by a continuation of the Council of Trent. He convoked such an assembly in 1556, but it was interrupted because of the papal war with Spain (Jedin 1960: 172).

Paul IV's successor, Pope Pius IV (r. 1559-1565) reopened the council because of the advance of Calvinism in France (Jedin 2003: 171). It was decided that this was a resumption of the Council of Trent rather than a new council. Sessions 17-25 took place during this third Tridentine period which lasted from January 1562 through December 1563. During this period there were a number of important decrees issued. On July 16, 1562, the council issued its decree on the doctrine of Holy Communion under both species and the communion of young children. On September 17, 1562, the council promulgated its doctrine and canons on the sacrifice of the Mass. July 15, 1563 saw the approval of the doctrine and canons on the sacrament of Holy Orders, and November 11, 1563 saw the approval of the doctrine and canons on the sacrament of marriage. The doctrine on marriage also included the decree Tamesti containing canons for a reform of marriage. On December 3, 1563, the council approved its decree on purgatory, and on the same day it issued its decree on the invocation, veneration, and relics of the saints and on sacred images. December 3, 1563 was also the date for the promulgation of the $D e$ cree on a General Reform, and December 4, 1563 was the date for the council's decree on indulgences.

The council ended with a bull of confirmation followed by the "Tridentine Rules' for the Prohibition of Books (1564), and the Tridentine Profession of Faith (1564).

\section{Reforms of the Council: Doctrinal and Disciplinary}

The reforms of the Council of Trent are found in both its doctrinal decrees and its disciplinary documents specifically directed to Church reform. With regard to the doctrinal documents, it can, of course, be argued that clarifying and defining doctrines concerning Scripture, Tradition, original sin, justification, and the sacraments is in itself an expression of reform. The reform of the Church is intimately linked to sound doctrine, and Trent's clear teaching on many topics, especially the sacraments, helped renew the Church's understanding of what she believes in the light of divine revelation. The Council of 
Trent in this sense can be understood as an expression of the Counter-Reformation because the doctrinal decrees reassert and clarify Catholic teachings in opposition to Protestant challenges.

Many of the Protestants believed the Bible was the sole rule of truth. Trent, however, reaffirmed the Catholic belief that the 'saving truths and norms of conduct ... are contained in the written books and the unwritten traditions that have come down to us' (Denzinger-Hünermann 2012: n. 1501, p. 370). Many Protestants also preached justification by faith alone apart from works. Trent, however, taught that 'faith without hope and charity neither unites a man perfectly with Christ nor makes him a living member of his body' (Denzinger-Hünermann 2012: n. 1531, p. 378).

Most of the Protestants believed there were only two sacraments, baptism and the Lord's Supper. The Council of Trent, however, affirmed seven sacraments as instituted by Jesus Christ our Lord (Denzinger-Hünermann 2012: n. 1601, p. 389). The Protestant denial of the sacrament of holy orders meant a break from apostolic tradition and the establishment of ecclesial communities lacking bishops and priests. This was a radical break that deprived the Protestants of the five sacraments that depend on bishops and priests as ministers, viz., holy orders, confirmation, the Eucharist, penance, and extreme unction. The Protestants also denied the Mass as a true sacrifice that re-presents Christ's sacrifice at Calvary in an unbloody manner. The Protestants for the most part rejected penance as a sacrament (though the Lutherans retained it as an ecclesiastical rite). This rejection was a blow to the penitential system of the Church.

Many of the Protestants rejected Catholic beliefs and practices such as Purgatory, indulgences, and devotion to relics and icons. The Council of Trent seemed to concede that there were abuses concerning these beliefs and practices. The response of the council, though, was to respond to the abuses rather than to reject Catholic beliefs. For example, with regard to Purgatory, the council states that bishops 'should not permit opinions that are doubtful and tainted with error to be spread and exposed, and they should forbid 'those things that belong to the realm of curiosity or superstition or smack of dishonorable gain' as 'scandalous and injurious to the faithful' (DenzingerHünermann 2012: n. 1820, p. 429). With regard to indulgences, Trent expressed its desire 'to correct and punish the abuses that have crept in and are the occasion for heretics to blaspheme this distinguished name of indulgences' (Denzinger-Hünermann 2012: n. 1835, p. 431). Therefore, the council 'enacts in general by this present decree that all base gain for securing indulgences ... should be totally abolished' (Denzinger-Hünermann 2012: n. 1835 , p. 431).

The Council of Trent's Decree on the Invocation, Veneration, and Relics of the Saints and on Sacred Imagesof December 3, 1563 is clearly a response to the 
Protestant rejection of these Catholic practices. The council affirms all of these practices and explains the biblical and theological reasons for them. The council also explains the difference between veneration of images of Christ, the Virgin Mary, and the saints and the blind trust in images 'as once was done by the Gentiles who placed their hope in idols' (cf. Psalm 135:1517); and the definition of the 787 Second Council of Nicaea is referred to for support (Denzinger-Hünermann 2012: n. 1823, p. 430). The Council likewise recognized that sacred images of the saints can strengthen the faith of the people. By looking at these images, the people are inspired by 'the miracles of God through the saints and their salutary example is put before the eyes of the faithful, who can thank God for them, shape their own lives and conduct in imitation of [them], and be aroused to adore and love God and to practice devotion' (Denzinger-Hünermann 2012: n. 1824, p.430).

As with Purgatory and indulgences, the Council of Trent was aware of the possible abuses regarding relics and sacred images. The following instruction, therefore, was given:

The holy council earnestly desires to root out utterly any abuses that may have crept into these holy and saving practices, so that no representations of false doctrines should be set up that give occasion of dangerous error to the unlettered... All superstition must be removed from invocation of the saints, veneration of the relics, and use of sacred images; all aiming at base profit must be eliminated; all sensual appeal must be avoided ... That these points may be carried out more faithfully, the holy council lays it down that no one in any place ... may erect or see to the erection of any unusual image unless it has been approved by the bishop. Nor are any new miracles to be accepted or new relics recognized without the bishop similarly examining and approving them (Denzinger-Hünermann 2012: n. 1825 , p. 430$)$.

The Council of Trent, in response to the Protestant denial of marriage as a sacrament, condemned under anathema any who denied matrimony as 'truly and properly one of the sacraments of the law of the Gospel, instituted by Christ the Lord' (Denzinger-Hünermann 2012: n. 1801, p. 426). The council also affirmed the indissolubility of marriage and condemned those who claimed the Church was in error 'for having taught and for still teaching that in accordance with the evangelical and apostolic doctrine [cf. Matthew 5:32; 19:9; Mark 10:11f; Luke 16:18; 1 Corinthians 7:11] the marriage bond cannot be dissolved because of adultery on the part of one of the spouses and that neither of the two, not even the innocent one who has given no cause for infidelity, can contract another marriage during the lifetime of the other, and that the husband who dismisses an adulterous wife and marries again and the wife who dismisses an adulterous husband and marries again are both guilty of adultery (Denzinger-Hünermann 2012: n. 1807, p. 426). 
The council also enacted extensive reforms for the sacrament of marriage, especially with respect to secret or clandestine marriages. These secret marriages were considered true and valid marriages as long as they were entered into freely and the Church has not made them invalid.

Likewise, marriages freely contracted by children still living at home are true and valid marriages even if they took place without parental consent. The council, though, wished to avoid the problems connected with such marriages, and therefore mandated that henceforth 'before a marriage is contracted, an announcement of those intending to marry shall be made publicly during Mass by the parish priest on three successive feast days'. Moreover, 'the marriage must then take place in open church' with the priest questioning the couple and 'in the presence of two or three witnesses' (DenzingerHünermann 2012: nos. 1814-1815, p. 428).

As can be seen, the Council of Trent included many teachings and rules to avoid abuses and bring about reform in the discipline of the sacraments and Catholic devotional life. In each of the three periods of the council, there also were decrees that were specifically disciplinary in nature with many of them aimed at the reform of the clergy. During the first period of thecouncil (1545-1547) there was a Decree on the residence of bishops and others of lower rank. One of the chief concerns of this decree was the problem of absentee bishops who 'abandon the flocks committed to them and completely neglect the guardianship of their flocks' (Tanner 1990: 682). In order to address this problem, the council required bishops to forfeit part of their year's revenue for unbroken absences of six months or more without a 'just and reasonable explanation' (Tanner 1990:682).

Another problem addressed by this decree was that of priests who collect benefices from the churches they are supposed to serve but who are absent from these churches. In order to address this problem, the council required bishops to assign substitutes and provide them with 'the appropriate part of the revenue' derived from the church when the pastor is absent (Tanner 1990: 683). In this way, the bishop will 'ensure that the care of souls is in no way neglected' (Tanner 1990: 683).

During the second period of the Council of Trent (1551-1552) two decrees on reform were issued. The first decree was entitled Decretum super reformatione, and it was issued during session 13 of the council. This decree reaffirmed the hope that bishops will reside in the churches (i.e. dioceses) assigned to them. It also reminded bishops that 'they are shepherds not oppressors, and they are to preside over their subjects but not lord it over them; they are to love them as children and as brothers and take pains by exhortation and counsel to deter them from what is unlawful so they may not be obliged, when they do wrong, to restrain them by inappropriate penalties' (Tanner 1990: 698). The decree reminds bishops of their right and duty to 
punish their subjects, including priests, who have committed crimes. It recognizes, though, that some of those punished might make false charges against their bishops even though they have been justly reprimanded. Causes against bishops must be supported by witnesses of good reputation and these charges 'shall be referred to the supreme pontiff and decided by him' (Tanner 1990: 701).

The other decree on reform during the second Tridentine period of the council was entitled Decretum de reformatione, and it was issued during session 14. This decree warns bishops about ordaining men to the priesthood who are 'unsuitable, untrained, and ignorant, who have been rejected by their own bishop as incapable and unworthy' (Tanner 1990: 715). This decree also includes regulations for religious and clerics. It reminds clerics of their need to wear 'the proper clerical dress befitting their order and dignity and in keeping with the regulation and command of their bishop' (Tanner 1990: 716). The decree forbids ordaining those guilty of homicide, and clerics who commit homicide are 'to be cut off permanently from every ecclesiastical order, benefice and office' (Tanner 1990: 717). If someone kills another by selfdefense or accident, a dispensation is needed in order to be ordained or to continue the 'ministry of the altar' (Tanner 1990: 717). These dispensations can be granted by the local bishop or, in some cases, by a neighboring bishop or metropolitan.

The third period of the Council of Trent (1562-1563) was when the most significant disciplinary decrees were approved. On February 26, 1562 during session 18 the council issued a Decree on the choice of books and on inviting all to the council under public protection. This decree expressed a need to develop policies that will protect the Catholic faithful 'from suspect and dangerous books by which the corrupt doctrine contained in them is spread far and wide' (Tanner 1990: 723). In light of this need, the council decided that 'the fathers elected for this examination of censures and books should consider what needs to be done ... so that this holy council may separate out these diverse and strange teachings like weeds from the wheat of Christian truth' (Tanner 1990: 723-724). This decision would come to fruition after the close of the council with the 'Tridentine Rules' for the Prohibition of Books, Confirmed in the Constitution Dominici gregis custodiae, March 24, 1564 (Denzinger-Hünermann 2012: nos. 1851-1861, pp. 433-435). There had been earlier versions of the Index authorized by popes, but the 'Tridentine Rules' governed the Church's official Index until it was abolished on June 14, 1966 (Acta Apostolicae Sedis 48, 1966: 445). After this abolition, the Congregation for the Doctrine of the Faith took over the duty to examine books of suspect doctrine.

The third period of the Council of Trent had some decrees that applied doctrinal principles to pastoral situations. Among these were the decree on 
Teaching on Communion under both kinds and of children issued on July 16, 1562 during session 21 (Tanner 1990: 726-728).

This decree contained a very important declaration on the Church's authority over the administration of the sacraments:

Furthermore, [the holy council] declares that, in the administration of the sacraments-provided their substance is preserved-there has always been in the Church the power to determine or modify what she judged more expedient for the benefit of those receiving the sacraments or for the reverence due to the sacraments themselves-according to the diversity of circumstances, times, and places (Denzinger-Hünermann 2012: n. 1728, 415).

The Council cited 1 Corinthians 11:34 in support of this authority where Paul tells the Corinthians that he will give them directions about other things. The Church, therefore, had the authority for 'just and serious reasons' to approve the custom of receiving communion under one of the two species. Because the entire Christ is received under only one of the two species 'those who receive under only one species are not deprived of any grace necessary for salvation' (Denzinger-Hünermann 2012: n. 1729, 415).

With regard to the reception of communion for children under the age of reason, the council made it clear that they are not under an obligation to receive holy communion because 'after rebirth by the water of baptism [cf. Titus 3:5] and incorporation in Christ, they are not at that age able to lose the grace they have received of being children of God' (Denzinger-Hünermann 2012: n. 1730, pp. 415-416).

The third Tridentine period contained some other decrees related to the discipline of the sacraments. The Decree on things to be observed and avoided in celebrating Mass was issued on September 17, 1562 during session 22 (Tanner 1990: 736-737). This decree stipulated that for the holy sacrifice of the Mass 'every effort and attention must be given to carrying it out with the greatest possible interior cleanliness and purity of heart, and in an outwardly devout and reverent manner' (Tanner 1990: 736). Bishops were instructed to root out anything related to superstition or greed regarding priests who make transactions for the celebration of Masses. They were also directed not to permit wandering or unknown priests to celebrate Mass, and they 'must not allow anyone whose guilt is public and notorious either to serve at the altar or take part in divine worship' (Tanner 1990: 736). With regard to liturgical worship, bishops were advised to 'keep out of their churches the kind of music in which a base and suggestive element is introduced into the organ playing or singing, and similarly all worldly activities, empty and secular conversation, walking about, noises and cries, so that the house of God may truly be called and be seen to be a house of prayer' (Tanner 1990: 737). Bishops likewise 'should banish from the church any idea of a particular number of 
masses and candles which derives more from the cult of superstition than from true religion, and teach people the nature and source of the very precious and heavenly effect of this most holy sacrifice' (Tanner 1990: 737).

The Decree on the request for the granting of the chalice was issued on September 17, 1562 during session 22 (Tanner 1990: 741). The Holy Roman Emperor Ferdinand I (r. 1556-1562) and Duke Albert V of Bavaria wished Trent to consider allowing communion under both species. The response was 'to refer the whole matter to our most holy lord ... so that in his unrivaled wisdom he may judge what will be best for the Christian community and most salutary for those requesting the use of the chalice' (Tanner 1990: 741). This decision to refer the matter to 'our most holy lord' (i.e. the pope) opened the way for Pius IV in 1564 to grant permission to several German dioceses to allow communion under both species in the hope that this would lead the Protestants to return to the Catholic Church. When not many Protestants returned because of this permission and the "enthusiasm of German Catholics for the lay chalice flagged, the permission was revoked in Bavaria in 1571, and in 1584 in all of Austria except Bohemia' (Bihlmeyer-Tüchle 1966: 110).

The third Tridentine period was also when the Canons on the reform of marriage - known as Tamesti-were issued during session 24 on November 11, 1563 (Tanner 1990: 755-759). As we have already seen, one of the main concerns was to stop the practice of marriages contracted in secret. These secret marriages sometimes led to a spouse being abandoned and not having any proof that the marriage had been established.

In addition to these decrees of applied doctrine, there were also more general decrees on reform issued during the different sessions of the third Tridentine period. The Decree on reform during the July 16, 1562 session 21 (Tanner 1990: 728-732) was concerned with the reform of the clergy. Bishops were warned about greed and accepting gifts in exchange for granting ecclesiastical ranks. They were instructed about overseeing the proper staffing of parishes and their right to form new parishes as needed. Bishops were likewise reminded of their duty to make sure parish churches are not served by 'illiterate and incompetent rectors' as well as by those 'who live in a base and scandalous fashion' (Tanner 1990: 730). Priests who 'persist incorrigibly in their evil ways' can be deprived by bishops 'of their benefices according to the sacred canons', and bishops can 'set aside any exemption or appeal' for such priests (Tanner 1990: 730).

The Decree on reform issued during session 22 of September 17, 1562 also dealt with the reform of the clergy. Those who serve the faithful as ministers of divine worship must 'fashion their whole life and habits' so that 'by dress, gesture, gait, speech and in every other way they express only what is serious, moderate and wholly devout' (Tanner 1990: 737). Bishops are directed to 
enforce already existing rules for clerics regarding 'loose living, feasting, dances, gambling, and offences of all kinds' (Tanner 1990: 738).

The Decree on reform of July 15, 1563 (session 23) contains 18 canons concerned with the reform of the clergy and, in a particular way, with the formation of future priests. In addition to addressing the problem of absentee bishops and pastors, these canons lay out regulations for admittance to minor orders and the establishment of seminaries. No one may be given a benefice before age 14 (canon 6). No one should be advanced to the subdiaconate before age 22; the diaconate before 23; and the priesthood before age 25 (canon 12). Those ordained to the subdiaconate and the diaconate 'should be of good repute and already tested in minor orders' (canon 13). Moreover, they 'should be well-educated, trained in all that belongs to the exercise of their order and with hope that by God's help they can live a celibate life' (Tanner 1990: 749). Bishops are instructed to establish seminaries for the training of future priests (canon 18). These seminaries must form future priests in piety and virtue and provide them with proper scriptural, theological, and liturgical studies. Seminarians must 'attend mass every day, confess their sins at least once a month, receive the body of our Lord Jesus Christ as often as their confessor judges, and serve in the cathedral and other churches in the area on feast days' (Tanner 1990: 751). Bishops should 'punish the difficult and incorrigible and those who spread bad habits with severity, and expel them if need be; and they will take utmost care to remove all obstacles from such a worthy and holy foundation and promote all that preserves and strengthens it' (Tanner 1990: 751).

At session 24 of November 11, 1563 another Decree on reform was issued, and it contained 21 canons (Tanner 1990: 759-773). Among other things, it reminded bishops of their duty to exercise their office of preaching as often as possible (canon 4). It made it clear that criminal charges against bishops may be heard only by metropolitans or bishops chosen by the pope (canon 5). It stipulated that those who commit public crimes that lead to public scandal should receive a penalty that is publicly imposed (canon 8). Canon 18 notes that it is of highest import for the salvation of souls that parishes be governed by worthy and qualified men' (Tanner 1990: 770). Bishops, therefore, must appoint suitable priests to take care of parishes following the death or resignation of the pastor.

During the final session of the council (session 25) of December 3-4, 1563, there was the Decree on regulars and nuns consisting of 22 chapters (Tanner 1990: 776-784). These chapters were mostly concerned with restoring discipline to the monastic life in places where discipline had collapsed. Some of the chapters, though, apply to male and female mendicants (e.g. chapter 3). The council wanted to make sure that poverty is properly followed (chapter 2 ) and that there is no deceit 'in the election of any superiors, abbots ... 
generals and abbesses and other women superiors' (chapter 6). The council also wished to ensure that no one would 'in any way force a virgin or widow or any other woman to enter a monastery against her will ... or to take the habit of a religious institute' (chapter18). It likewise imposed 'a similar anathema on those who in any manner and without good reason obstruct the holy desire of virgins or other women to take the habit or make profession' (Tanner 1990:782).

The Decree on general reform (Decretum de reformatione generali) consisting of 21 chapters was approved on December 3, 1563 during the 25th and final session of the council (Tanner 1990: 784-796). This is the decree on reform most referred to in reference to the Council of Trent, and it would set the standards for all the reforms envisioned by the council. Some of the more significant resolutions are the following: the need to eliminate nepotism and clerical greed (chapter 1); the need for true obedience to the pope (chapter 2 ); the need for the sword of excommunication 'to be wielded with great caution and reserve' (chapter 3); the need for pastors to manifest hospitality and charity, especially toward 'pilgrims, the sick, the old, and the poor' (chapter 8); the need to eliminate clerical unchastity and 'the uncleanness of concubinage' (chapter 14); the need to stop bishops from being subservient 'towards royal ministers, rulers, and barons' (chapter 16); the need to put an end to the 'detestable practice of dueling' (chapter 19); and the need for Catholic secular rulers to 'recall their subjects to due reverence towards the clergy, both parish priests and those of higher ranks' and to respect 'the freedom of the Church' (chapter 20).

\section{The Catechism of the Council of Trent}

Following the Decree on general reform, the council approved some final decrees on indulgences; the choice of foods and fasting; the index of books, the catechism, the breviary, and missal; the place of ambassadors; and the reception and observance of the council's decrees (Tanner 1990: 796-798). The need for a catechism was discussed during the 24th session of the council in the fall of 1563 (McHugh and Callan 1982: xxiv), and its need was also implicit in canon 7 of the Decree on reform of November 11, 1563. This canon instructs bishops to make sure that parish priests explain the power and benefit of the sacraments to the people, and this is to be done "even in the vernacular tongue ... according to the form laid down by the holy council' (Tanner 1990: $764)$.

The form laid down by the council was realized in the Catechism of the Council of Trent, which is often referred to as The Roman Catechism. During the Patristic period, catechesis usually involved memorizing the Our Father and the Creed (McHugh and Callan 1982: xi). 
During the Middle Ages, parish priests instructed the faithful in the vernacular on the Creed, the Commandments and the Sacraments, and by the early 15 th century, the most common catechetical books used by priests centered on 'four main points of Christian doctrine, namely, the Creed, the Sacraments, the Commandments, and the Lord's Prayer' (McHugh and Callan, 1982: xviii). Thus, it's no surprise that the Catechism of the Council of Trent contains four parts: the Creed, the Sacraments, the Ten Commandments, and the Lord's Prayer.

In January of 1563, the Council of Trent established a committee to work on the Catechism under the presidency of Cardinal Giralomo Seripando (1492-1563). After the death of Seripando on March 17, 1563, the presidency of the committee was entrusted to the young Cardinal and future saint, Carlo Borromeo (1538-1584), who was the nephew of Pope Pius IV (r. 1559-1565). Originally the plan was to draw up a manual for children and poorly catechized adults, but 'it was decided to prepare a much more thorough work to be used by parish priests in their instruction of the faithful' (McHugh and Callan, 1982: xxiv).

The Catechism was not completed until July of 1566, several years after the December 4, 1563 close of the Council of Trent. The original drafting team included a number of Dominicans as well as some Franciscans, Augustinians, and diocesan priest-theologians. Pius IV died on December 9, 1565. His successor, St. Pius V (r. 1566-1572) appointed 'a number of expert theological advisors to examine every statement of the catechism from the viewpoint of doctrine', including 'Cardinal Sirlet and the two Dominicans, Thomas Manriquez and Eustachius Locatelli' (McHugh and Callan 1982: xxv). The full title was Catechismus ex decreto SS. Concilii Tridentini ad parochos PII V. Pont. Max. jussu editus (Catechism of the Council of Trent for Parish Priests Issued by Order of Pius V, the Supreme Pontiff).

The Catechism refers frequently to the decrees of the Council of Trent, but it also has many references to Sacred Scripture, the Fathers-especially Augustine-and to St. Thomas Aquinas. The Catechism went through many editions and translations up into the 20th century and its influence has been significant. Popes such as Clement XIII (r. 1758-1769), Leo XIII (18781903), and St. Pius X (1903-1914) have strongly encouraged its use (McHugh and Callan 1982: xxiii-xxiv).

The contribution of the Catechism of the Council of Trent to reform is to be found in both its content and its purpose. The content of the Catechism has contributed to reform because of its emphasis on a correct understanding of the faith, especially with regard to the sacraments. As has been seen, one of the main concerns of the Council of Trent was a reform in the morals of the clergy and the faithful. In this regard, the Catechism places heavy emphasis on having priests known for their 'integrity of life and morals' and their 
ability 'to instruct the people in the mysteries of the Christian faith and the precepts of the divine law' (McHugh and Callan 1982: 335).

The Catechism also includes a thorough treatment of the Ten Commandments, which are binding on all of the faithful. Observing the commandments brings forth many blessings to the faithful and to the Church. Those who observe the law of God 'are filled with pure delights, with knowledge of divine mysteries, and are blessed with plenteous joys and rewards both in this life and in the life to come' (McHugh and Callan 1982: 362) The Catechism also promotes holiness through the sacraments and through prayer. Through prayer the faithful are able overcome sin and temptation and to do all things according to God's will and pleasure and 'to be ready to bear all things rather than depart from His holy will in the slightest degree' (McHugh and Callan 1982: 533).

Both the content and the purpose of the Catechism had a significant influence on reform. Because the text was for parish priests, it reinforced their duty to feed the flock with sound faith and morals.

\section{Assessing the Success of the Tridentine Reforms}

How successful were the reforms of the Council of Trent? From a Catholic viewpoint, there can be no doubt that the Council of Trent had and continues to have a significant role in the life of the Church. According to Jedin, the three agents for the Catholic-Reformation-Counter-Reformation were 'the papacy, the Jesuits, and the Council of Trent' (O'Malley 2000: 56).

Because the council of Trent involved popes in the cause of reform, it helped to bring about a reform of the papacy itself. Since the closing of Trent, the popes of the Catholic Church have been prayerful and committed men. Whatever their shortcomings none of these popes have sunk to the level of the immorality and naked ambition of Renaissance popes like Alexander VI.

The Jesuits represented a renewed evangelical and intellectual spirit during the time of the Catholic Reformation. Because the Jesuits had only received papal approbation in 1540, just a handful of them were present at the council. The Jesuits of the late 16th and early 17 th century, however, embodied the spirit of the Council of Trent, especially with regard to responding to the doctrinal challenges of the Protestants. The Jesuit St. Robert Bellarmine (1542-1621) is the most outstanding example of this Counter-Reformationi.e. counter-Protestant-spirit. Jesuit missionaries like Matteo Ricci (c. 15521610) — a missionary to China — and Roberto de Nobili (1577-1656) — a missionary to India-show that the Catholic Reformation was not simply an effort to counter the Protestant reform movements; it was also an effort to spread the Gospel of Jesus Christ to people who had never encountered it.

Historians differ on how successful the reforms of the Council of Trent were. Many Protestant historians, of course, believe that the council failed to 
address adequately the doctrinal concerns of reformers such as Luther and Calvin. The Catholic historian Thomas Bokenkotter, however, believes the Council of Trent's Decree on Justification contributed to a spiritual renewal because it understood spiritual perfection 'as involving a high degree of personal activity - combining an active striving after self-control, the acquisition of virtue, and a zeal for the good works of mercy and charity' (Bokenkotter 2004: 250). This spirituality found expression in saints of the Post-Tridentine period such as St. Francis de Sales (1567-1622), St. Jane Frances de Chantal (1572-1641), and St. Vincent de Paul (1581-1660).

Hubert Jedin agrees with Bokenkotter that the Council of Trent helped to bring about 'a renewal and a strengthening of ecclesiastical life' along with a 'new Catholic piety and mysticism, the revival of scholastic theology, the emergence of positive theology, and the art and culture of the baroque age' (Jedin 2003: 174). Jedin, however, believes that the Tridentine Profession of Faith of November 13, 1564 lacks a 'definition of the Church or of the papal primacy', but this is because 'at that time the opposing conceptions still in existence could not be reconciled' (Jedin 2003: 174).

The historian Brad Gregory has a more sober assessment of the success of the Tridentine reform. He points out that both Protestants and Catholics were dependent on secular rulers for protection and influence. The popes were aware that if they 'unduly antagonized Catholic rulers, they risked defiance ranging from polite inaction to the specter of full-scale withdrawal in the manner of Henry VIII of England' (Gregory 2012: 152). In fact, because of French Gallicanism 'the decrees of the Council of Trent were never officially sanctioned by the French crown despite the extraordinary dynamism of seventeenth-century French Catholicism' (Gregory 2012: 152).

The Jesuit historian John W. O’Malley has a somewhat mixed assessment of the implementation of the council's reforms. He notes positive changes in the education and morals of the parish clergy as well of bishops residing in their dioceses (O’Malley 2000: 66). He also recognizes that most of these significant changes 'must be attributed to post-Tridentine reformers like Carlo Borromeo of Milan, who through synods and other means further articulated the standards for clerical life and ministry legislated by Trent' (O'Malley 2000: 67). O’Malley, however, believes that-except for Paul IV and Pius Vfew of the popes of the era 'took "Catholic Reform" as the emotional center of their lives’ (O’Malley 2000: 123).

\section{Conclusion}

The Council of Trent contributed greatly to the internal spiritual and doctrinal renewal of the Catholic Church. It helped to clarify what the Catholic Church believes in response to Protestant objections. The council also helped to address clerical corruption and immorality and stimulate a renewal of 
Catholic spirituality and religious life. In spite of these great contributions, the Council of Trent was not able to heal the divisions between the Catholic Church and the various Protestant ecclesial communities. It also could not overcome the growing movements of nationalism emerging during the early modern period. The Council of Trent, however, helped many Catholics remain firm in their beliefs as movements such as skepticism and secularism began to emerge. The Council of Trent was one of the great events of the Catholic Reformation and the Counter-Reformation. Its call for the moral renewal of the clergy and the faithful resonates with the Church today, which stands in need of a new reformatio in capite et in membris.

\section{Bibliography}

Acta Apostolicae Sedis (1966). Rome: Vatican Polyglot Press: 445.

Bettenson H and Maunder C (2011) (eds) Documents of the Christian ChurchFourth Edition. Oxford: Oxford University Press.

Bihlmeyer K and Tüchle H (1966) Church History Volume Three: Modern and Recent Times. V Mills V E and Muller F J (trans.) Westminster: Newman Press.

Bokenkotter T (2004) A Concise History of the Catholic Church. New York: Doubleday.

Denzinger H and Hünermann P (2012) (eds.) Compendium of Creeds, Definitions, and Declarations on Matters of Faith and Morals, 43rd edition. San Francisco: Ignatius Press.

Gregory BS (2012) The Unintended Reformation: How a Religious Revolution Secularized Society. Cambridge, MA: The Belknap Press of Harvard University Press.

Hildebrand HJ (1996) (ed) The Oxford Encyclopedia of the Reformation, volume 1. Oxford: Oxford University Press.

Jedin H (1960) Ecumenical Councils: An Historical Outline, Graf E (trans) New York: Herder and Herder.

Jedin H (2003) Trent, Council of. In Marthaler B (ed) New Catholic Encyclopedia, second edition, volume 14. Detroit: Thomson Gale, pp. 168-176.

McHugh JA and Callan CJ (1982) (trans) Catechism of the Council of Trent for Parish Priests. Rockford, IL: Tan Books and Publishers.

Olin J (1969) (ed) The Catholic Reformation: Savonarola to Ignatius Loyola. New York: Harper and Row.

O’Malley J W (2000) Trent and All That: Renaming Catholicism in the Early Modern Era. Cambridge, MA: Harvard Univeristy Press.

Tanner NP (1990) (ed) Decrees of the Ecumenical Councils, 2 volumes. London: Sheed and Ward. 